Article

\title{
Synthesis, Crystal Structures and Catalytic Activities of Two Copper Coordination Compounds Bearing an $\mathrm{N}, \mathrm{N}^{\prime}$-Dibenzylethylenediamine Ligand
}

\author{
Chao Liu *, Weiwei Zhang and Gaigai Cai \\ School of Chemistry and Chemical Engineering, Suzhou University, Suzhou 234000, China; \\ hgzhangweiwei@stu.ahszu.edu.cn (W.W.Z.); hgcaigaigai@stu.ahszu.edu.cn (G.G.C.) \\ * Correspondence: kykrliu@ahszu.edu.cn; Tel.: +86-557-2875018
}

Received: 25 May 2020; Accepted: 17 June 2020; Published: 21 June 2020

check for updates

\begin{abstract}
Two copper coordination compounds bearing an $\mathrm{N}, \mathrm{N}^{\prime}$-dibenzylethylenediamine ligand, namely $\left[\mathrm{Cu}_{3} \mathrm{~L}\left(\mathrm{CH}_{3} \mathrm{COO}\right)_{6}\right]_{\mathrm{n}}(\mathbf{1})$ and $\left[\left(\mathrm{CuCl}_{4}\right) \cdot\left(\mathrm{C}_{6} \mathrm{H}_{5} \mathrm{CH}_{2} \mathrm{NH}_{2} \mathrm{CH}_{2}\right)_{2}\right](2)\left(\mathrm{L}=\mathrm{N}, \mathrm{N}^{\prime}\right.$-dibenzylethylenediamine) were synthesized by the ethanol refluxing method. Powder X-ray diffraction (PXRD), infrared spectra (IR), elemental analyses, and single crystal X-ray diffraction were used to characterize and verify their structures. Structural analyses showed that the asymmetric unit of compound (1), composed of two $\mathrm{Cu}(\mathrm{II})$ cations, three acetate anions, and half of the ligand, was bridged by one acetate to obtain an infinite 1D chain structure. The analyses further showed that the asymmetric unit of compound (2), composed of two crystallographically independent $\left[\mathrm{C}_{6} \mathrm{H}_{5} \mathrm{CH}_{2} \mathrm{NH}_{2} \mathrm{CH}_{2}\right]^{+}$units, four chloride anions, and one central $\mathrm{Cu}$ (II) cation is connected into an infinite 2D network structure by the hydrogen bonding interactions. The copper compounds were used to catalyze the decomposition of $\mathrm{H}_{2} \mathrm{O}_{2}$, and the results showed that both of the compounds exhibited excellent catalytic activities under optimized conditions.
\end{abstract}

Keywords: N,N'-dibenzylethylenediamine; crystal structure; catalyst; coordination compound

\section{Introduction}

Among transition metal coordination compounds, copper coordination compounds occupy a vital position in organometallic chemistry due to their abundant coordination structures and potential applications in various fields [1-5]. In recent years, the catalytic activities of copper coordination compounds with various organic ligands have attracted extensive attention from chemists [6-9]. To develop novel and efficient catalysts, copper ions coordinated to a suitable ligand with multiple coordination sites and strong coordination abilities have been assembled into different copper coordination compounds [10,11]. Diamine and its derivatives are an important class of organic compounds with highly flexible $\mathrm{N}, \mathrm{N}$-donor atoms that can coordinate to different metal ions, thus producing a variety of mononuclear [12-14], binuclear [15-17], and polynuclear metal coordination compounds with excellent catalytic activities [18-20].

Hydrogen peroxide is a kind of oxidant [21], bleaching agent [22], and disinfectant [23] that is widely used in pharmaceutical, textile and chemical industries. [24-26]. As a result of the excessive use of $\mathrm{H}_{2} \mathrm{O}_{2}$, local soil and water resources have become severely polluted [27]. Therefore, it is particularly important to develop a practical catalytic system for the decomposition of $\mathrm{H}_{2} \mathrm{O}_{2}$. Presently, metal oxides, metal salts, and some coordination compounds have been used to catalyze the decomposition reaction of $\mathrm{H}_{2} \mathrm{O}_{2}$, and considerable results have been obtained [28-30]. In order to better catalyze the decomposition of $\mathrm{H}_{2} \mathrm{O}_{2}$, practical and efficient catalytic systems have become a research hotspot for chemical workers [31].

Therefore, the challenge we faced was to determine how to obtain coordination compounds with strong catalytic activities and low environmental pollution potential. With this purpose, we designed 
and synthesized two novel copper coordination compounds bearing an $\mathrm{N}, \mathrm{N}^{\prime}$-dibenzylethylenediamine ligand. Simultaneously, the catalytic activities of the coordination compounds were investigated for the decomposition reaction of $\mathrm{H}_{2} \mathrm{O}_{2}$ under mild conditions.

\section{Materials and Methods}

\subsection{General Considerations}

$\left(\mathrm{NH}_{4}\right)_{2} \mathrm{CuCl}_{4} \cdot 2 \mathrm{H}_{2} \mathrm{O}$ and $\mathrm{N}, \mathrm{N}^{\prime}$-dibenzylethylenediamine were obtained from Shanghai Aladdin Bio-Chem Technology Co., Ltd. in Shanghai, China. Other reagents, such as $\mathrm{KMnO}_{4}, \mathrm{H}_{2} \mathrm{O}_{2}, \mathrm{Cu}(\mathrm{OAc})_{2} \cdot \mathrm{H}_{2} \mathrm{O}$, and $\mathrm{CuCl}_{2} \cdot 2 \mathrm{H}_{2} \mathrm{O}$, were obtained from commercial sources and were used as received.

An FTS-40 spectrometer (Bio-Rad, Santa Clara, CA, USA) with a KBr pellet was used to collect the FT-IR spectra of the compounds in the $400-4000 \mathrm{~cm}^{-1}$ range. A DX-2600 diffractometer (Dandong, Liaoning, China) with $\mathrm{Cu}-\mathrm{K} \alpha$ radiation was employed to obtain powder $\mathrm{X}$-ray diffractions at ambient temperature. A Vario Micro Cube elemental analyzer (Elementar, Frankfurt, Germany) was used to test the elemental analyses of compounds (1) and (2).

\subsection{Synthesis of $\left[\mathrm{Cu}_{3} \mathrm{~L}\left(\mathrm{CH}_{3} \mathrm{COO}\right)_{6}\right]_{n}(\mathbf{1})$}

An ethanol $(30 \mathrm{~mL})$ solution of $\mathrm{Cu}(\mathrm{OAc})_{2} \cdot \mathrm{H}_{2} \mathrm{O}(1.27 \mathrm{~g}, 2.12 \mathrm{mmol})$ was added to a $100 \mathrm{~mL}$ round-bottom flask with an ethanol $(10 \mathrm{~mL})$ solution of $\mathrm{N}, \mathrm{N}^{\prime}$-dibenzylethylenediamine $(0.50 \mathrm{~mL}$, $2.12 \mathrm{mmol}$ ). The reaction solution was stirred and heated at $78{ }^{\circ} \mathrm{C}$ for $24 \mathrm{~h}$ and the solution color gradually changed from light blue to deep blue. The reaction solvent was evaporated by vacuum distillation and the residue was carefully washed with n-hexane $(2 \times 5 \mathrm{~mL})$. The resulting solid was extracted with a co-solvent of dichloromethane and ethanol $\left(8 \mathrm{~mL}, \mathrm{~V}_{\text {dichloromethane }} / \mathrm{V}_{\text {ethanol }}=1 / 1\right)$. The blue crystalline solid of compound (1) was obtained upon standing the resulting solution for $48 \mathrm{~h}$ at room temperature in a $64 \%$ yield. Melting point: $215.0-216.5^{\circ} \mathrm{C}$. Anal. Calcd. for $\mathrm{C}_{28} \mathrm{H}_{38} \mathrm{Cu}_{3} \mathrm{~N}_{2} \mathrm{O}_{12}$ (Formula weight $=785.22$ ): C, 42.83; H, 4.88; N, 3.57\%; Found: C, 42.64; H, 5.11; N, 3.79\%. IR $\left(\mathrm{KBr}, \mathrm{cm}^{-1}\right)$ : 3426(s), 3066(w), 2978(m), 2924(s), 2765(s), 2689(m), 2568(m), 2404(m), 1564(s), 1400(s), 1301(w), 1023(m), 908(s), 842(w), 799(m), 744(s), 695(m), 646(s), $504(\mathrm{w})$.

\subsection{Synthesis of $\left[\left(\mathrm{CuCl}_{4}\right) \cdot\left(\mathrm{C}_{6} \mathrm{H}_{5} \mathrm{CH}_{2} \mathrm{NH}_{2} \mathrm{CH}_{2}\right)_{2}\right](2)$}

An ethanol $(30 \mathrm{~mL})$ solution of $\mathrm{CuCl}_{2} \cdot 2 \mathrm{H}_{2} \mathrm{O}(0.72 \mathrm{~g}, 4.24 \mathrm{mmol})$ was added to a $100 \mathrm{~mL}$ round-bottom flask with an ethanol $(10 \mathrm{~mL})$ solution of $\mathrm{N}, \mathrm{N}^{\prime}$-dibenzylethylenediamine $(1.00 \mathrm{~mL}, 4.24 \mathrm{mmol})$. After being added to two drops of diluted hydrochloric acid under stirring, the reaction solution was stirred and heated at $78^{\circ} \mathrm{C}$ for $24 \mathrm{~h}$; as a result, the solution color gradually changed from light blue to deep blue. The reaction solvent was evaporated by vacuum distillation and the residue was carefully washed with $\mathrm{n}$-hexane $(2 \times 5 \mathrm{~mL})$. The resulting solid was extracted with a co-solvent of $\mathrm{n}$-hexane and methanol (12 mL, $\left.\mathrm{V}_{\mathrm{n} \text {-hexane }} / \mathrm{V}_{\text {methanol }}=1 / 2\right)$. The blue crystalline solid of compound (2) was obtained upon standing the resulting solution for $24 \mathrm{~h}$ at room temperature in a $79 \%$ yield. Melting point: 189.5-190.5 ${ }^{\circ} \mathrm{C}$. Anal. Calcd. for $\mathrm{C}_{16} \mathrm{H}_{22} \mathrm{Cl}_{4} \mathrm{CuN}_{2}$ (Formula weight $=447.69$ ): $\mathrm{C}, 42.92 ; \mathrm{H}, 4.95 ; \mathrm{N}$, 6.26\%; Found: C, 43.21; H, 5.03; N, 6.06\%. IR $\left(\mathrm{KBr}, \mathrm{cm}^{-1}\right)$ : 3443(s), 3055(w), 2902(m), 2847(w), 2771(m), 2361(s), 2334(m), 1640(s), 1591(s), 1553(s), 1487(m), 1411(s), 1148(m), $1066(\mathrm{~m}), 1023(\mathrm{~m})$, 974(w), 842(w), 739(m), 701(s), 684(m), 631(w).

\subsection{X-ray Crystallography}

Single crystals with dimensions of $0.10 \times 0.12 \times 0.14 \mathrm{~mm}$ for compound (1) and $0.22 \times 0.25 \times 0.27 \mathrm{~mm}$ for compound (2) were selected for single-crystal X-ray diffraction analyses on a Bruker APEX-II CCD diffractometer (Bruker, Karlsruhe, Germany). The diffraction data were collected by graphite monochromated Mo-Ka radiation $(\lambda=0.71073 \AA$ ) at $296(2) \mathrm{K}$. The empirical absorption corrections were performed using the SADABS program. The crystal structures of compounds (1) and (2) were solved by direct methods using the SHELXT program [32] and were refined by full-matrix least-squares on $\mathrm{F}^{2}$ with 
the SHELXL 2018/3 program [33]. All non-hydrogen atoms were refined anisotropically and the hydrogen atoms were placed in the geometrically idealized positions. The crystallographic data for the compounds are given in Table 1 . The selected bond lengths $(\AA)$ and angles $\left(^{\circ}\right)$ of the compounds are summarized in Table S1 in Supplementary Materials.

Table 1. Crystallographic data for compounds (1) and (2).

\begin{tabular}{|c|c|c|}
\hline Compound & (1) & (2) \\
\hline Formula & $\mathrm{C}_{28} \mathrm{H}_{38} \mathrm{Cu}_{3} \mathrm{~N}_{2} \mathrm{O}_{12}$ & $\mathrm{C}_{16} \mathrm{H}_{22} \mathrm{C}_{14} \mathrm{CuN}_{2}$ \\
\hline Formula weight & 785.22 & 447.69 \\
\hline Temperature & $296(2)$ & $296(2)$ \\
\hline Crystal system & Monoclinic & Triclinic \\
\hline Space group & $\mathrm{C} 2 / \mathrm{c}$ & $P_{\overline{1}}$ \\
\hline$a(\AA)$ & $15.903(13)$ & $6.5935(9)$ \\
\hline$b(\AA)$ & $16.403(15)$ & 11.9953(18) \\
\hline$c(\AA)$ & $15.679(12)$ & $12.4736(17)$ \\
\hline$\alpha$ & 90.00 & $84.199(4)$ \\
\hline$\beta$ & $96.06(2)$ & $88.408(4)$ \\
\hline$\gamma$ & 90.00 & $77.972(4)$ \\
\hline Volume $\left(\AA^{3}\right)$ & $4067(6)$ & $959.9(2)$ \\
\hline$Z$ & 4 & 2 \\
\hline Density $($ calculated $) /\left(\mathrm{g} \cdot \mathrm{cm}^{-3}\right)$ & 1.283 & 1.549 \\
\hline$\mu\left(\mathrm{mm}^{-1}\right)$ & 1.605 & 1.694 \\
\hline$F(000)$ & 1612 & 458 \\
\hline Reflections collected & 13,134 & 6888 \\
\hline Unique reflections $\left(R_{\text {int }}\right)$ & $4648(0.064)$ & $3346(0.040)$ \\
\hline Gof & 1.026 & 1.057 \\
\hline Final $R$ indices $[I>2 \sigma(I)]$ & $R_{1}=0.0931, w R_{2}=0.2708$ & $R_{1}=0.0300, w R_{2}=0.0770$ \\
\hline$R$ indices (all data) & $R_{1}=0.1098, w R_{2}=0.2899$ & $R_{1}=0.0322, w R_{2}=0.0786$ \\
\hline Largest diff. peak and hole (e $\AA^{-3}$ ) & 0.96 and -1.13 & 0.30 and -0.49 \\
\hline
\end{tabular}

\subsection{Decomposition Reaction of Hydrogen Peroxide}

A synthesized compound $(1.0 \mathrm{mmol})$ was added to a $50 \mathrm{~mL}$ round-bottom flask with $\mathrm{N}, \mathrm{N}$-dimethy lformamide (DMF) $(5 \mathrm{~mL})$. An aqueous solution of $\mathrm{H}_{2} \mathrm{O}_{2}(10 \mathrm{~mL}, 30 \mathrm{wt} \%)$ was diluted 2 times with distilled water $(10 \mathrm{~mL})$ and carefully injected into the round-bottom flask. The decomposition reaction proceeded at room temperature for $24 \mathrm{~h}$ and the solution gradually became slightly turbid. The reaction process was monitored by hydrogen peroxide test paper. In order to measure the decomposition percentage of $\mathrm{H}_{2} \mathrm{O}_{2}$ in the presence of the catalyst, the residual $\mathrm{H}_{2} \mathrm{O}_{2}$ concentration was titrated by using a standard solution of $\mathrm{KMnO}_{4}$ [34].

\section{Results and Discussion}

\subsection{Structure Description of $\left[\mathrm{Cu}_{3} \mathrm{~L}\left(\mathrm{CH}_{3} \mathrm{COO}\right)_{6}\right]_{n}$}

The asymmetric unit of $\left[\mathrm{Cu}_{3} \mathrm{~L}\left(\mathrm{CH}_{3} \mathrm{COO}\right)_{6}\right]_{n}$ contains two $\mathrm{Cu}(\mathrm{II})$ cations, three acetate anions, and half of the ligand (Figure 1). The central $\mathrm{Cu} 1$ cation has the same coordination geometry as the $\mathrm{Cu} 1$ (ii) cation, where $\mathrm{Cu} 1$ cation is five-coordinated by five oxygen atoms $(\mathrm{O} 2, \mathrm{O} 3, \mathrm{O} 5, \mathrm{O} 1$ (ii) and O6(ii)) from five different bridging acetates in an $\eta^{1}$ mode. This leads to a square pyramidal $\mathrm{CuO}_{5}$ coordination geometry. The observed geometric parameter $\tau(0.003)$ reveals that the $\mathrm{Cu} 1$ cation lies in an almost perfect square pyramidal environment. The basal plane of the square pyramidal geometry is defined by four oxygen atoms (O2, O5, O1(ii), and O6(ii)) with Cu1-O bond lengths ranging from 1.976(5) to $1.989(5) \AA$, while the apical position is occupied by one oxygen atom (O3) from another acetate anion with the $\mathrm{Cu} 1-\mathrm{O} 3$ bond of 2.178(5) $\AA$. The $\mathrm{Cu1-O}$ bond lengths of the basal plane were found to be shorter than the apical $\mathrm{Cu} 1-\mathrm{O} 3$ bond length, which indicates that they are more stable than the $\mathrm{Cu} 1-\mathrm{O} 3$ bond. When the bond angles $\mathrm{O} 2-\mathrm{Cu} 1-\mathrm{O} 5$ of $88.1(2)^{\circ}, \mathrm{O} 2-\mathrm{Cu} 1-\mathrm{O} 6(\mathrm{ii})$ of 
90.6(2) ${ }^{\circ}$, O1(ii)-Cu1-O6(ii) of $89.4(2)^{\circ}$, and O1(ii)-Cu1-O5 of $89.8(2)^{\circ}$ were added, the sum equaled $357.9^{\circ}$, nearly equal to $360^{\circ}$, further confirming that the $\mathrm{Cu} 1$ cation is in an almost perfect square pyramidal environment. The adjacent $\mathrm{Cu}$ (II) cations (Cu1 and $\mathrm{Cu} 1(\mathrm{ii})$ ) are bridged by four acetates in a $\mu_{2}-\eta^{1}: \eta^{1}$-bridging coordination mode, forming a paddlewheel dinuclear $\mathrm{Cu}_{2}\left(\mathrm{CO}_{2}\right)_{4}$ building unit. The nonbonding Cu1 ... Cu1(ii) distance is 2.6274(16) $\AA$, which is in agreement with those of some similar copper compounds $[35,36]$. The $\mathrm{Cu} 2$ cation is four-coordinated by two nitrogen atoms (N1 and $\mathrm{N} 1(\mathrm{i})$ ) from the $\mathrm{N}, \mathrm{N}^{\prime}$-dibenzylethylenediamine ligand in an $\eta^{2}$ mode and two oxygen atoms ( $\mathrm{O} 4$ and $\mathrm{O} 4(\mathrm{i})$ ) from two bridging acetates in $\eta^{1}$ mode. This results in a square-planar $\mathrm{CuN}_{2} \mathrm{O}_{2}$ coordination geometry. The average bond length of $\mathrm{Cu} 2-\mathrm{O}$ is 1.976(5) and that of $\mathrm{Cu} 2-\mathrm{N}$ is 2.007(5) $\AA$, both of which correspond with the reported values $[37,38]$. The sums of the bond angles N1-Cu2-N1(i) of 85.1(2) ${ }^{\circ}$, O4(i)-Cu2-N1(i) of 94.7(2) ${ }^{\circ}, \mathrm{O} 4-\mathrm{Cu} 2-\mathrm{O} 4(\mathrm{i})$ of $93.5(2)^{\circ}$, and O4-Cu2-N1 of 94.7(2) ${ }^{\circ}$ when added up equal $368^{\circ}$, which is unequal to $360^{\circ}$, which confirms that the four-coordinated atoms and $\mathrm{Cu} 2$ cation are in an imperfect plane.
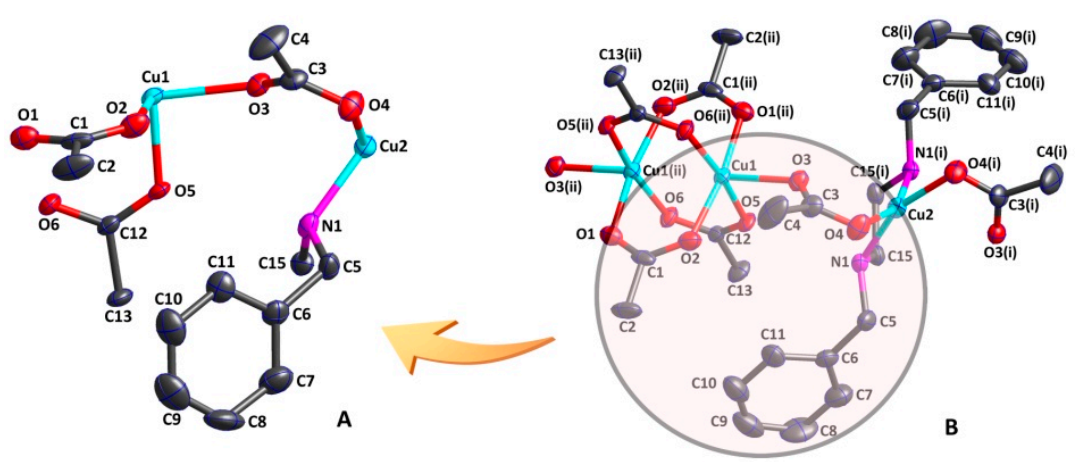

Figure 1. An asymmetric unit of compound (1) (A) and a secondary structure with a paddlewheel $\mathrm{Cu}_{2}\left(\mathrm{CO}_{2}\right)_{4}$ unit (B) (thermal ellipsoids at 30\% probability level). Symmetry codes: (i)1-x,y,3/2-z; (ii) $1 / 2-x, 3 / 2-y, 1-z$.

As shown in Figure 2, the $\mathrm{CuN}_{2} \mathrm{O}_{2}$ unit and the $\mathrm{Cu}_{2}\left(\mathrm{CO}_{2}\right)_{4}$ unit are bridged by one acetate in a $\mu_{2}-\eta^{1}: \eta^{1}$-bridging coordination mode, forming an infinite $1 \mathrm{D}$ chain along the a axis. In addition, there are weak intramolecular hydrogen bonds between the ligand and the acetate (Table S2). The nitrogen atom (N1) from the ligand acts as an H-donor to the oxygen atom (O5) from one acetate, forming the intramolecular hydrogen bond N1-H1 ... O5, which further stabilizes the 1D chain structure.

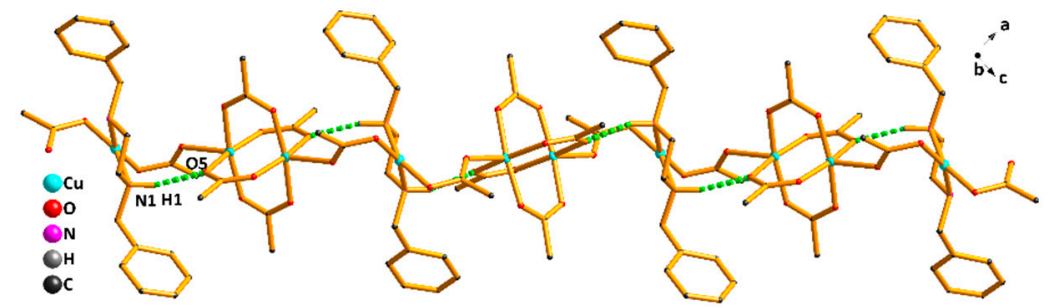

Figure 2. The 1D chain structure of compound (1).

\subsection{Structure Description of $\left[\left(\mathrm{CuCl}_{4}\right) \cdot\left(\mathrm{C}_{6} \mathrm{H}_{5} \mathrm{CH}_{2} \mathrm{NH}_{2} \mathrm{CH}_{2}\right)_{2}\right]$}

Figure 3 shows that the asymmetric unit of $\left[\left(\mathrm{CuCl}_{4}\right) \cdot\left(\mathrm{C}_{6} \mathrm{H}_{5} \mathrm{CH}_{2} \mathrm{NH}_{2} \mathrm{CH}_{2}\right)_{2}\right]$ consists of four chloride anions, one central $\mathrm{Cu}(\mathrm{II})$ cation, and two crystallographically independent $\left[\mathrm{C}_{6} \mathrm{H}_{5} \mathrm{CH}_{2} \mathrm{NH}_{2} \mathrm{CH}_{2}\right]^{+}$units. The $\mathrm{Cu} 1$ cation is four-coordinated by four chlorine anions $(\mathrm{Cl1}, \mathrm{Cl} 2, \mathrm{Cl} 3$, and $\mathrm{Cl} 4)$ in $\eta^{1}$ mode, resulting in a distorted tetrahedral $\left[\mathrm{CuCl}_{4}\right]^{2-}$ coordination geometry. The four $\mathrm{Cu} 1-\mathrm{Cl}$ bond lengths are $2.2529(7)$, $2.2199(7), 2.2648(7)$, and 2.2643(7) $\AA$, respectively, none of which are equal to one another. The bond angles $\mathrm{Cl} 3-\mathrm{Cu} 1-\mathrm{Cl} 4$ of $91.80(2)^{\circ}, \mathrm{Cl1}-\mathrm{Cu} 1-\mathrm{Cl} 4$ of $98.22(2)^{\circ}, \mathrm{Cl} 1-\mathrm{Cu} 1-\mathrm{Cl} 2$ of $96.54(2)^{\circ}$, and $\mathrm{Cl} 2-\mathrm{Cu} 1-\mathrm{Cl} 3$ of $102.21(2)^{\circ}$ differ significantly from the standard tetrahedral angle of $109.5^{\circ}$. Both of the bond angles 
$\left(\mathrm{Cl} 2-\mathrm{Cu} 1-\mathrm{Cl} 4\right.$, which is $141.65(2)^{\circ}$, and $\mathrm{Cl} 2-\mathrm{Cu} 1-\mathrm{Cl} 4$, which is $\left.135.02(2)^{\circ}\right)$ are significantly greater than other $\mathrm{Cl}-\mathrm{Cu} 1-\mathrm{Cl}$ bond angles. This indicates that the $\mathrm{Cu}$ (II) cation is in a distorted tetrahedral coordination environment. However, the ligand does not coordinate to the $\mathrm{Cu}$ (II) cation; instead, it reacts with diluted hydrochloric acid to give its acid salt $\left[\mathrm{H}_{2} \mathrm{~L}\right]^{2+}$. The acid salt $\left[\mathrm{H}_{2} \mathrm{~L}\right]^{2+}$ assumes the role of the counter cation, which can balance the valence charge of the $\left[\mathrm{CuCl}_{4}\right]^{2-}$ anion. Through the electrostatic interaction between positive and negative ions, the asymmetric unit is further stabilized.

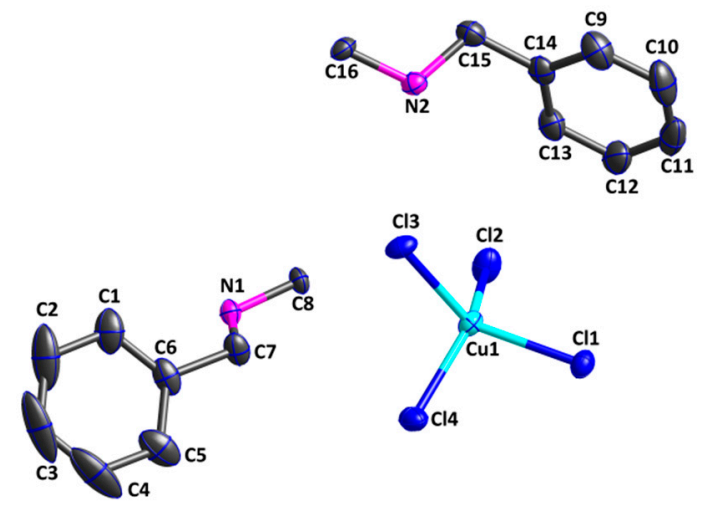

Figure 3. An asymmetric unit of compound (2) (thermal ellipsoids at 30\% probability level).

Moreover, there is an abundance of intermolecular and intramolecular hydrogen bonds in compound (2) (Table S2) that benefit the stability of the crystal structure. As shown in Figure 4, the nitrogen atoms from the $\mathrm{N}, \mathrm{N}^{\prime}$-dibenzylethylenediamine ligand act as an $\mathrm{H}$-donor to the chlorine atoms from $\left[\mathrm{CuCl}_{4}\right]^{2-}$ unit, forming the hydrogen bonds N1-H1A ... Cl1(iii) of 2.37 $\AA$, N1-H1B ... Cl4(iv) of $2.51 \AA$, and N2-H2B ... Cl3(v) of $2.37 \AA$. The intermolecular hydrogen bonds play an important role in constructing the stable 1D chain structure of compound (2). Another noticeable characteristic of compound (2) is how the intermolecular hydrogen bonding interactions exist among 1D chains, such as N2-H2A ... Cl1(iv) of $2.81 \AA$ and C16-H16B . . C Cl4(v) of $2.82 \AA$. Under the weak hydrogen bonding interactions, the $1 \mathrm{D}$ chain structure is further connected and extended, resulting in an infinite 2D network structure in Figure 5.

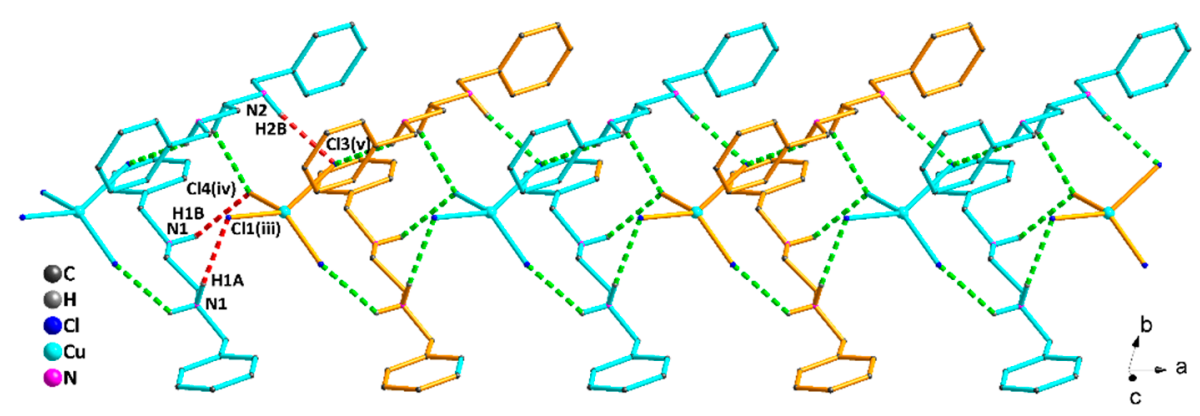

Figure 4. The $1 \mathrm{D}$ chain structure of compound (2). Symmetry codes: (iii) 1-x,-y,1-z; (iv) 1+x,y,z; (v) $1-x, 1-y, 1-z$.

\subsection{PXRD Analysis}

To verify the phase purities of the crystal samples, PXRD experiments were further carried out on compounds (1) and (2) at room temperature. The simulated and experimental PXRD patterns for compounds (1) and (2) are presented in Figures S1 and S2, respectively. The peaks in the experimental curves matched with those in the simulated curves generated from the single crystal X-ray data, thus confirming that the phase purities of the synthesized compounds are correct. The reflection intensities of the experimental patterns were not in agreement with the corresponding simulated patterns; this may be attributed to the different orientations of the crystal samples during the 
test. Additionally, the elemental analyses of compounds (1) and (2) support the results of the PXRD experiments.

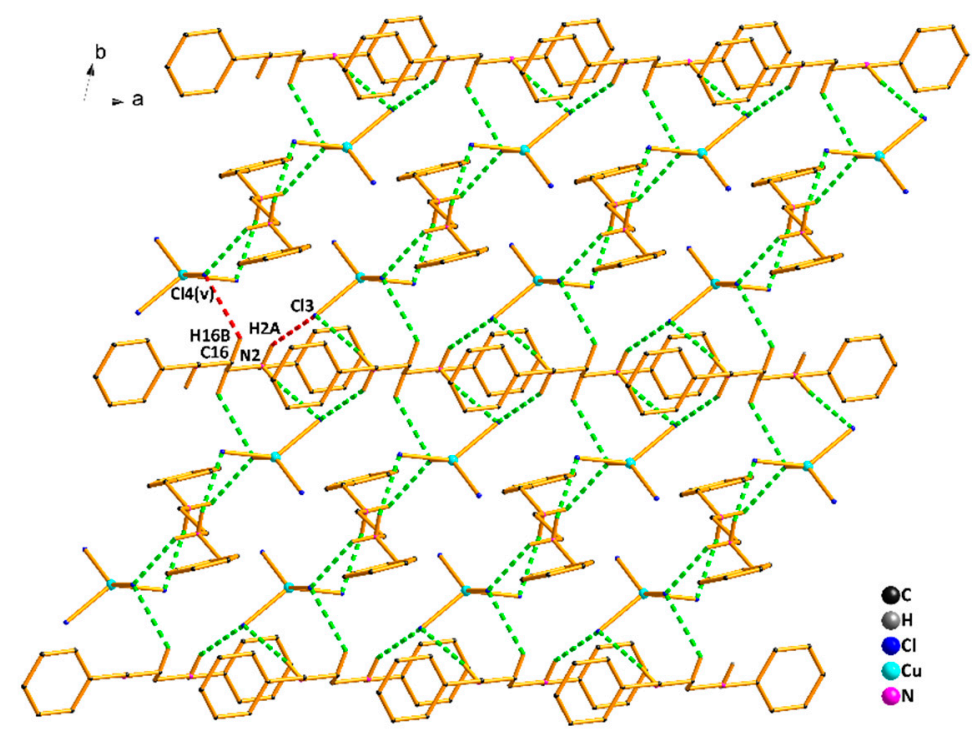

Figure 5. The 2D network structure of compound (2).Symmetry codes: (iii) $1-x,-y, 1-z$; (iv) $1+x, y, z$; (v) $1-x, 1-y, 1-z$.

\subsection{Catalytic Activities of the Compounds}

Hydrogen peroxide, which has severely polluted local soil and water sources because of its extensive use in production and life, could instead be efficiently decomposed under the catalysis of metal compounds [28-30]. To optimize the favorable reaction conditions, such as the $\mathrm{pH}$ value and catalyst loading, the decomposition reaction of $\mathrm{H}_{2} \mathrm{O}_{2}$ catalyzed by the synthesized compounds was carried out under different conditions. The results are given in Tables 2 and 3.

Firstly, the decomposition reaction of $\mathrm{H}_{2} \mathrm{O}_{2}$ with compound (1) as a catalyst with the $\mathrm{pH}$ value of 8 was used as a model reaction to evaluate the effect of the catalyst loading on this reaction. When the catalyst loading was $1.0 \mathrm{mmol}$, the decomposition rate of $\mathrm{H}_{2} \mathrm{O}_{2}$ reached $94 \%$ (Entry 3). Although the decomposition reaction may efficiently occur under the catalysis of compound (1) with a catalyst loading range between 1.0 and $1.6 \mathrm{mmol}$, the decomposition rate remained almost unchanged (Entries 3-5), which implied that an excessive amount of catalyst could not effectively improve the decomposition rate. When the catalyst loading was reduced from 1.0 to $0.4 \mathrm{mmol}$, the decomposition percentage decreased significantly from 94 to 39\% (Entries 1-3). The experimental data revealed that $\mathrm{H}_{2} \mathrm{O}_{2}$ could not be fully decomposed with the catalyst loading below $1.0 \mathrm{mmol}$. In comparison with compound (1), compound (2) exhibited stronger catalytic activities in catalyzing the decomposition of $\mathrm{H}_{2} \mathrm{O}_{2}$. Surprisingly, when the loading of compound (2) was $1.0 \mathrm{mmol}$, the decomposition percentage reached nearly $100 \%$ (i.e., $99 \%$ ) (Entry 8 ). In addition, regardless of the loading of compound (2) was increased or decreased, the decomposition percentage of $\mathrm{H}_{2} \mathrm{O}_{2}$ had the same rule as compound (1) (Entries 6 and 7, 9 and 10). Therefore, the most suitable catalyst loading was $1.0 \mathrm{mmol}$, and thus was be selected for the following studies. The catalytic activities of the $\mathrm{N}, \mathrm{N}^{\prime}$-dibenzylethylenediamine ligand were also explored. As we expected, the residual concentration of $\mathrm{H}_{2} \mathrm{O}_{2}$ remained almost constant (Entry 11), which confirmed that the ligand had no catalytic activities in the decomposition reaction. According to the related literature [39], $\mathrm{CuCl}_{2} \cdot 2 \mathrm{H}_{2} \mathrm{O}$ and $\mathrm{Cu}(\mathrm{OAc})_{2} \cdot \mathrm{H}_{2} \mathrm{O}$ are also excellent catalysts in the decomposition of $\mathrm{H}_{2} \mathrm{O}_{2}$. We found that the decomposition percentages of $84 \%$ and $77 \%$ were obtained with a catalyst loading of $1.0 \mathrm{mmol}$, respectively (Entries 12 and 13). The copper metal contents of $\mathrm{CuCl}_{2} \cdot 2 \mathrm{H}_{2} \mathrm{O}$ and $\mathrm{Cu}(\mathrm{OAc})_{2} \cdot \mathrm{H}_{2} \mathrm{O}$ were higher than those of the synthesized compounds, and thus may cause more serious environmental damage. The catalytic activities of $\left(\mathrm{NH}_{4}\right)_{2} \mathrm{CuCl}_{4} \cdot 2 \mathrm{H}_{2} \mathrm{O}$ were also surveyed (Entry 14), and from this, we found that the decomposition percentage of $81 \%$, 
which is lower than the $99 \%$ of compound (2), proved that the ligand unit in this compound also plays an important role in the catalytic process.

Table 2. The effects of catalyst loading on the decomposition reaction of $\mathrm{H}_{2} \mathrm{O}_{2}$.

\begin{tabular}{|c|c|c|c|}
\hline Entry & Catalyst & Catalyst Loading (mmol) & Decomposition Percent (\%) \\
\hline 1 & compound (1) & 0.4 & 39 \\
\hline 2 & & 0.7 & 78 \\
\hline 3 & & 1.0 & 94 \\
\hline 4 & & 1.3 & 95 \\
\hline 5 & & 1.6 & 95 \\
\hline 6 & compound (2) & 0.4 & 44 \\
\hline 7 & & 0.7 & 82 \\
\hline 8 & & 1.0 & 99 \\
\hline 9 & & 1.3 & 99 \\
\hline 10 & & 1.6 & 99 \\
\hline 11 & Ligand & 1.0 & 0 \\
\hline 12 & $\mathrm{Cu}(\mathrm{OAc})_{2} \cdot \mathrm{H}_{2} \mathrm{O}$ & 1.0 & 77 \\
\hline 13 & $\mathrm{CuCl}_{2} \cdot 2 \mathrm{H}_{2} \mathrm{O}$ & 1.0 & 84 \\
\hline 14 & $(\mathrm{NH} 4)_{2} \mathrm{CuC}_{14} \cdot 2 \mathrm{H}_{2} \mathrm{O}$ & 1.0 & 81 \\
\hline
\end{tabular}

To study the effect of $\mathrm{pH}$ levels on the rate of the decomposition of $\mathrm{H}_{2} \mathrm{O}_{2}$, we tested the catalytic activities of the coordination compounds with a catalyst loading of $1.0 \mathrm{mmol}$ under different $\mathrm{pH}$ conditions. We found that the $\mathrm{pH}$ value of the solution had a considerable influence on the catalytic activities of the coordination compounds. Under acidic conditions, the catalytic activities of the coordination compounds were very poor (Entries 1 and 2, 5 and 6), but the catalytic activities strengthened significantly with the increase in $\mathrm{pH}$ value. When the solution was weakly alkaline, such as at $\mathrm{pH} 8$, the decomposition percentages of $\mathrm{H}_{2} \mathrm{O}_{2}$ reached $94 \%$ and $99 \%$,respectively (Entries 4 and 10). The experimental results showed that when the $\mathrm{pH}$ value of the solution was higher than 9 , the decomposition rate of $\mathrm{H}_{2} \mathrm{O}_{2}$ decreased significantly; this may be due to the side reactions between the compounds and the hydroxyl ion. We concluded that the weak alkaline solution with the $\mathrm{pH}$ value of 8 is suitable for the decomposition of $\mathrm{H}_{2} \mathrm{O}_{2}$.

Table 3. The effect of $\mathrm{pH}$ on the decomposition reaction of $\mathrm{H}_{2} \mathrm{O}_{2}$.

\begin{tabular}{cccc}
\hline Entry & Catalyst & pH & Decomposition Percent (\%) \\
\hline 1 & compound (1) & 5 & 44 \\
2 & & 6 & 65 \\
3 & & 7 & 81 \\
4 & & 8 & 94 \\
5 & & 9 & 88 \\
6 & & 10 & 79 \\
7 & compound (2) & 5 & 51 \\
8 & & 6 & 69 \\
9 & & 7 & 86 \\
10 & & 8 & 99 \\
11 & & 9 & 80 \\
12 & & 10 & 61 \\
\hline
\end{tabular}

Considering the decomposition rate and the concepts of green chemistry, compound (2) rather than compound (1) and the copper salts was found to be a more suitable catalyst with a catalyst loading of $1.0 \mathrm{mmol}$ and a $\mathrm{pH}$ value of 8 for the decomposition reaction of $\mathrm{H}_{2} \mathrm{O}_{2}$. 


\section{Conclusions}

In this study, two copper coordination compounds bearing an $\mathrm{N}, \mathrm{N}^{\prime}$-dibenzylethylenediamine ligand were synthesized. The crystal structure of compound (1) revealed that the $\mathrm{Cu} 1$ cation, as well as the $\mathrm{Cu1}$ (ii) cation, lies in an almost perfect square pyramidal $\mathrm{CuO}_{5}$ coordination environment and that the $\mathrm{Cu} 2$ cation lies in a distorted square planar $\mathrm{CuN}_{2} \mathrm{O}_{2}$ coordination geometry. Both the $\mathrm{CuN}_{2} \mathrm{O}_{2}$ unit and the $\mathrm{Cu}_{2}\left(\mathrm{CO}_{2}\right)_{4}$ unit were bridged to generate an infinite 1D chain structure by the bidentate acetate. The crystal structure of compound (2) revealed that the $\mathrm{Cu} 1$ (II) cation forms a distorted tetrahedral $\left[\mathrm{CuCl}_{4}\right]^{2-}$ coordination environment. Two $\left[\mathrm{C}_{6} \mathrm{H}_{5} \mathrm{CH}_{2} \mathrm{NH}_{2} \mathrm{CH}_{2}\right]^{+}$units and the $\left[\mathrm{CuCl}_{4}\right]^{2-}$ anion constituted the asymmetric unit of compound (2), which is further connected to an infinite 2D network structure via the hydrogen bonding interactions. In addition, examination on their catalytic activities indicated that compounds (1) and (2) with a catalyst loading of $1.0 \mathrm{mmol}$ and a $\mathrm{pH}$ value of 8 could efficiently catalyze the decomposition of $\mathrm{H}_{2} \mathrm{O}_{2}$. Considering the decomposition rate and the concepts of green chemistry, compound (2) is a more suitable catalyst for the decomposition of $\mathrm{H}_{2} \mathrm{O}_{2}$ than compound (1).

Supplementary Materials: The following are available online at http://www.mdpi.com/2073-4352/10/6/528/s1: Selected bond lengths $(\AA)$ and angles $\left({ }^{\circ}\right.$ ) of compounds (1) and (2); Table S2. Hydrogen bonding parameters for compounds (1) and (2); Figure S1. PXRD patterns of compound (1); Figure S2. PXRD patterns of compound (2). CCDC-1988490 for compound (1) and CCDC-1988519 for compound (2).

Author Contributions: Conceptualization, C.L.; methodology, C.L.; investigation, W.Z.; funding acquisition, C.L.; project administration, G.C.; formal analysis, W.Z.; writing-original draft preparation, C.L.; writing-review and editing, C.L. and G.C. All authors have read and agreed to the published version of the manuscript.

Funding: This work was funded by the National Natural Science Foundation of China (No. 21977001), the Academic Leader Program of Suzhou University (No. 2018XJHB02), and the Innovation and Entrepreneurship Training Program for College Students in Anhui Province (No. 201910379079).

Acknowledgments: The authors would like to thank Anhui Medical University and Anhui Key Laboratory of Spin Electron and Nanomaterials for the characterization of the compounds.

Conflicts of Interest: The authors declare no conflicts of interest.

\section{References}

1. Wang, H.; Sorolla, M.; Wang, X.; Jacobson, A.J.; Wang, H.; Pillai, A.K. Synthesis, crystal structures and in vitro anticancer activities of two copper(II) coordination compounds. Transit. Met. Chem. 2018, 44, $237-245$. [CrossRef]

2. Călinescu, M.; Fiastru, M.; Bala, D.; Mihailciuc, C.; Negreanu-Pîrjol, T.; Jurcă, B. Synthesis, characterization, electrochemical behavior and antioxidant activity of new copper(II) coordination compounds with curcumin derivatives. J. Saudi Chem. Soc. 2019, 23, 817-827. [CrossRef]

3. Sran, B.S.; Sharma, S.; Hundal, G. Self-assembly and supramolecular isomerism in copper (II) coordination compounds of pyridine-4-carboxamide based ligand. Inorg. Chim. Acta 2018, 486, 74-82. [CrossRef]

4. He, G.; Li, J.; Wang, Z.; Liu, C. Synthesis of a fluorogenic probe for thiols based on a coumarin schiff base copper complex and its use for the detection of glutathione. Tetrahedron 2017, 73, 272-277. [CrossRef]

5. Wang, Y.; Li, S.; Wang, L.; Qu, S.; Liu, K. Geometric relaxation in a copper complex and its limitation by polymer immobilization: Structure, characterization and photophysical analysis. J. Lumin. 2017, 192, $269-276$. [CrossRef]

6. Muthukumar, P.; Pannipara, M.; Al-Sehemi, A.G.; Moon, D.; Anthony, S.P. Polymorphs of a copper coordination compound: Interlinking active sites enhance the electrocatalytic activity of the coordination polymer compared to the coordination complex. Crystengcomm 2020, 22, 425-429. [CrossRef]

7. Zhao, N.; Li, Y.; Gu, J.; Fernandes, T.A.; Kirillova, M.V.; Kirillov, A.M. New copper(II) coordination compounds assembled from multifunctional pyridine-carboxylate blocks: Synthesis, structures, and catalytic activity in cycloalkane oxidation. Molecules 2018, 24,6. [CrossRef]

8. Amini, M.; Nikkhoo, M.; Tekantappeh, S.B.; Farniab, S.M.F.; Mahmoudi, G.; Büyükgüngör, O. Synthesis, characterization and catalytic properties of a copper complex containing decavanadate nanocluster, $\mathrm{Na} 2[\mathrm{Cu}(\mathrm{H} 2 \mathrm{O}) 6] 2\{\mathrm{~V} 10 \mathrm{O} 28 \cdot 4 \mathrm{H} 2 \mathrm{O}\}$. Inorg. Chem. Commun. 2017, 77, 72-76. [CrossRef] 
9. Sindhuja, D.; Vasanthakumar, P.; Bhuvanesh, N.; Karvembu, R. Catalytic assessment of copper(I) complexes and a polymer analog towards the one-pot synthesis of imines and quinoxalines. Eur. J. Inorg. Chem. 2019, 2019, 3940-3941. [CrossRef]

10. Nesterova, O.V.; Bondarenko, O.E.; Pombeiro, A.J.L.; Nesterov, D.S. Phenoxazinone synthase-like catalytic activity of novel mono- and tetranuclear copper(II) complexes with 2-benzylaminoethanol. Dalton Trans. 2020, 49, 4710-4724. [CrossRef]

11. Yang, Y.Y.; He, M.Q.; Li, M.X.; Huang, Y.Q.; Chi, T.; Wang, Z.-X. Ferrimagnetic copper-carboxyphosphinate compounds for catalytic degradation of methylene blue. Inorg. Chem. Commun. 2018, 94, 5-9. [CrossRef]

12. Narulkar, D.D.; Patil, A.R.; Naik, C.C.; Dhuri, S.N. Synthesis, characterization, cis-ligand substitution and catalytic alkane hydroxylation by mononuclear nickel(II) complexes stabilized with tetradentate tripodal ligands. Inorg. Chim. Acta. 2015, 427, 248-258. [CrossRef]

13. Naeimi, H.; Moradian, M. Encapsulation of copper(I)-Schiff base complex in NaY nanoporosity: An efficient and reusable catalyst in the synthesis of propargylamines via A3-coupling (aldehyde-amine-alkyne) reactions. Appl. Catal. A 2013, 467, 400-406. [CrossRef]

14. Myznikov, L.V.; Fisher, A.I.; Dmitrieva, U.N.; Artamonova, T.V.; Zevatskii, Y.E. Novel mixed complexes of copper(II) and ethylenediamine: Synthesis, crystal structure, and catalytic activity in the cross-coupling reaction of 1-phenyl-5H-tetrazole-5-thiol and iodobenzene. Russ. J. Gen. Chem. 2018, 88, 495-499. [CrossRef]

15. Wu, X.Y.; Ren, Z.G.; Lang, J.P. Ni(II) tetraphosphine complexes as catalysts/initiators in the ring opening polymerization of $\varepsilon$-caprolactone. Dalton Trans. 2013, 43, 1716-1723. [CrossRef]

16. Rajković, S.; Ašanin, D.P.; Živković, M.D.; Djuran, M.I. Synthesis of different pyrazine-bridged platinum(II) complexes and $1 \mathrm{H}$ NMR study of their catalytic abilities in the hydrolysis of the N-acetylated 1-methionylglycine. Polyhedron 2013, 65, 42-47. [CrossRef]

17. Chinnaraja, E.; Arunachalam, R.; Choudhary, M.K.; Kureshy, R.I. Binuclear Cu(II) chiral complexes: Synthesis, characterization and application in enantioselective nitroaldol (Henry) reaction. Appl. Organomet. Chem. 2016, 30, 95-101. [CrossRef]

18. Mutti, F.G.; Zoppellaro, G.; Gullotti, M.; Santagostini, L. Biomimetic modelling of copper enzymes: Synthesis, characterization, EPR analysis and enantioselective catalytic oxidations by a new chiral trinuclear copper(II) complex. Eur. J. Inorg. Chem. 2009, 4, 554-566. [CrossRef]

19. Zhu, L.; Liu, D.; Wu, L.; Feng, W.; Zhang, X.; Wu, J.; Fan, D.; Lü, X.; Lu, R.; Shi, Q. A trinuclear [Zn3(L)2(OAc)2] complex based on the asymmetrical bis-Schiff-base ligand $\mathrm{H} 2 \mathrm{~L}$ for ring-opening copolymerization of $\mathrm{CHO}$ and MA. Inorg. Chem. Commun. 2013, 37, 182-185. [CrossRef]

20. Sreedaran, S.; Bharathi, K.S.; Rahiman, A.K.; Jagadish, L.; Kaviyarasan, V.; Narayanan, V. Synthesis, electrochemical, magnetic, catalytic and antimicrobial studies of $\mathrm{N}$-functionalized cyclam based trinuclear copper(II) and nickel(II) complexes. J. Incl. Phenom. Macrocyclic Chem. 2010, 66, 297-306. [CrossRef]

21. Shi, F.; Chen, Y.; Sun, L.; Zhang, L.; Hu, J. Hydroxylation of phenol catalyzed by different forms of Cu-alginate with hydrogen peroxide as an oxidant. Catal. Commun. 2012, 25, 102-105. [CrossRef]

22. Penha, E.S.D.; Cabral, E.L.; Gama, T.S.D.; Oliveira, C.A.D. Use of 35\% hydrogen peroxide in tooth bleaching in different clinical time intervals: How long does sensitivity last, and at what times is it more exacerbated. Biochem. J. 2018, 34, 1095-1104. [CrossRef]

23. Dong, Y.; Duan, C.; Sheng, Q.; Zheng, J. Preparation of Ag@zeolitic imidazolate framework-67 at room temperature for electrochemical sensing of hydrogen peroxide. Analyst 2019, 144, 521-529. [CrossRef] [PubMed]

24. Asghar, A.; Raman, A.A.A.; Daud, W.M.A.W. Advanced oxidation processes for in-situ production of hydrogen peroxide/hydroxyl radical for textile wastewater treatment: A review. J. Cleaner Prod. 2015, 87, 826-838. [CrossRef]

25. Al-Sheddi, E.S.; Farshori, N.N.; Al-Oqail, M.M.; Musarrat, J.; Al-Khedhairy, A.A.; Siddiqui, M.A. Protective effect of lepidium sativum seed extract against hydrogen peroxide-induced cytotoxicity and oxidative stress in human liver cells (HepG2). Pharm. Biol. 2016, 54, 314-321. [CrossRef] [PubMed]

26. Radko, M.; Kowalczyk, A.; Mikrut, P.; Witkowski, S.; Mozgawa, W.; Macyk, W.; Chmielarz, L. Catalytic and photocatalytic oxidation of diphenyl sulphide to diphenyl sulfoxide over titanium dioxide doped with vanadium, zinc, and tin. RSC Adv. 2020, 10, 4023-4031. [CrossRef]

27. Chen, X.; Yang, J.; Zhang, A.; Liu, H.; Sun, J.; Liu, J.; Meng, F. Pollution characteristics and chemical behaviors of atmospheric hydrogen peroxide. Res. Environ. Sci. 2016, 29, 334-342. [CrossRef] 
28. Han, Q.; Ni, P.; Liu, Z.; Dong, X.; Wang, Y.; Li, Z.; Liu, Z. Enhanced hydrogen peroxide sensing by incorporating manganese dioxide nanowire with silver nanoparticles. Electrochem. Commun. 2014, 38, 110-113. [CrossRef]

29. Salem, I.A.; El-Sheikh, M.; Zaki, A.B. ChemInform abstract: Kinetics and mechanisms of decomposition reaction of hydrogen peroxide in presence of metal complexes. Int. J. Chem. Kinet. 2000, 32, $643-666$. [CrossRef]

30. Deng, H.H.; Wu, G.W.; He, D.; Peng, H.P.; Liu, A.L.; Xia, X.H.; Chen, W. Fenton reaction-mediated fluorescence quenching of N-acetyl-1-cysteine-protected gold nanoclusters: Analytical applications of hydrogen peroxide, glucose, and catalase detection. Analyst 2015, 140, 7650-7656. [CrossRef]

31. Chen, W.; Zhang, F.; Kong, G.; Cai, S.; Wang, W.; Du, J.; Wu, L. Fast decomposition of hydrogen peroxide by Zeolitic imidazolate framework-67 crystals. Mater. Lett. 2019, 239, 94-97. [CrossRef]

32. Sheldrick, G.M. SHELXT-integrated space-group and crystal-structure determination. Acta Cryst. 2015, A71, 3-8. [CrossRef] [PubMed]

33. Sheldrick, G.M. Crystal structure refinement with SHELXL. Acta Cryst. 2015, 71, 3-8. [CrossRef]

34. Yin, J. Study of acetone ketal copper ethylenediamine synthetic and catalytic properties. J. Weifang Univ. 2015, 15, 32-34. [CrossRef]

35. Zhu, W.; Lin, C.; Zheng, Y.; Zhu, H. Two dinuclear copper(II) coordination polymers constructed from m-hydroxybenzoic acid and N-donor ligands: Synthesis, crystal structures, and magnetic properties. Transit. Met. Chem. 2016, 41, 87-96. [CrossRef]

36. Liu, C.; Liu, Y.; Zhang, L.; Jiang, K.; Zhang, L. Two coordination compounds bearing bis(2-dimethylaminoethyl) ether: Syntheses, crystal structures and catalytic application to the Henry reaction. Chem. Res. Chin. Univ. 2018, 34, 358-362. [CrossRef]

37. Zhang, L.W.; Li, X.Y.; Kang, Q.P.; Liu, L.Z. Structures and fluorescent and magnetic behaviors of newly synthesized $\mathrm{Ni}(\mathrm{II})$ and $\mathrm{Cu}(\mathrm{II})$ coordination compounds. Crystals 2018, 8, 173. [CrossRef]

38. Karthik, K.; Qadir, A.M. Synthesis and crystal structure of a new binuclear copper(II) carboxylate complex as a precursor for copper(II) oxide nanoparticles. J. Struct. Chem. 2019, 60, 1126-1132. [CrossRef]

39. Yan, X.; Wang, B.; Ma, H.; Gao, F. Synthesis and catalytic properties of transition metal complexes with unsymmetrical Schiff base. Chem. Res. J. Appl. 2006, 18, 621-624. [CrossRef] 